Or -500

ORNL/TM-5685

\title{
Pressure Vessels for Coal Conversion Systems
}

\author{
D. A. Canonico \\ G. C. Robinson \\ W. R. Martin
}

\section{OAK RIDGE NATIONAL LABORATORY}

OPERATED BY UNION CARBIDE CORPORATION FOR THE ENERGY RESEARCH AND DEVELOPMENT ADMINISTRATION 


\section{DISCLAIMER}

This report was prepared as an account of work sponsored by an agency of the United States Government. Neither the United States Government nor any agency Thereof, nor any of their employees, makes any warranty, express or implied, or assumes any legal liability or responsibility for the accuracy, completeness, or usefulness of any information, apparatus, product, or process disclosed, or represents that its use would not infringe privately owned rights. Reference herein to any specific commercial product, process, or service by trade name, trademark, manufacturer, or otherwise does not necessarily constitute or imply its endorsement, recommendation, or favoring by the United States Government or any agency thereof. The views and opinions of authors expressed herein do not necessarily state or reflect those of the United States Government or any agency thereof. 


\section{DISCLAIMER}

Portions of this document may be illegible in electronic image products. Images are produced from the best available original document. 
Printed in the United States of America. Available trom National Technical Information Service

U.S. Department of Commerce

5285 Port Royal Road, Springfield, Virginia 22161

Price: Printed Copy $\$ 3.50$; Microfiche $\$ 2.25$

This report was prepared as an account of work sponsored by the United States Government. Neither the United States nor the Energy Research and Development Administration/United States Nuclear Regulatory Commission, nor any of their employees, nor any of their contractors, subcontractors, or their employees, makes any warranty, expreş or implied, or assumes any leyal liability ur responsibility for the accuracy, completeness or usefulness of any information, apparatus, product or process disclosed, or represents that its use would not infringe privately owned rights. 
Contract No. W-7405-eng-26

METALS AND CERAMICS DIVISION

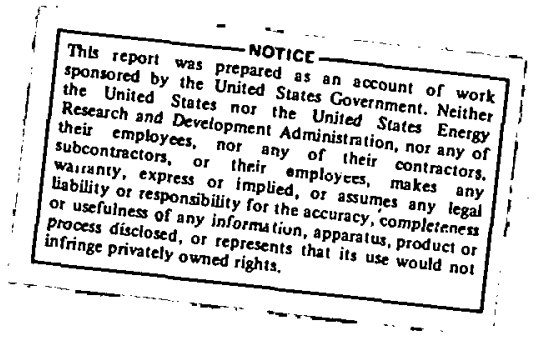

PRESSURE VESSELS FOR COAL CONVERSION SYSTEMS

D. A. Canonico, G. C. Robinson, and W. R. Martin

Date Published: November 1976

OAK RIDGE NATIONAL LABORATORY

Oak Ridge, Tennessee 37830

operated by

UNION CARBIDE CORPORATION

for the

ENERGY RESEARCH AND DEVELOPMENT ADMINISTRATION

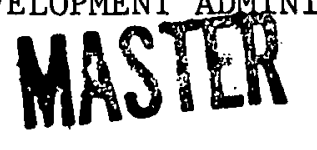


THIS PAGE

WAS INTENTIONALLY LEFT BLANK 


\section{CONTENTS}

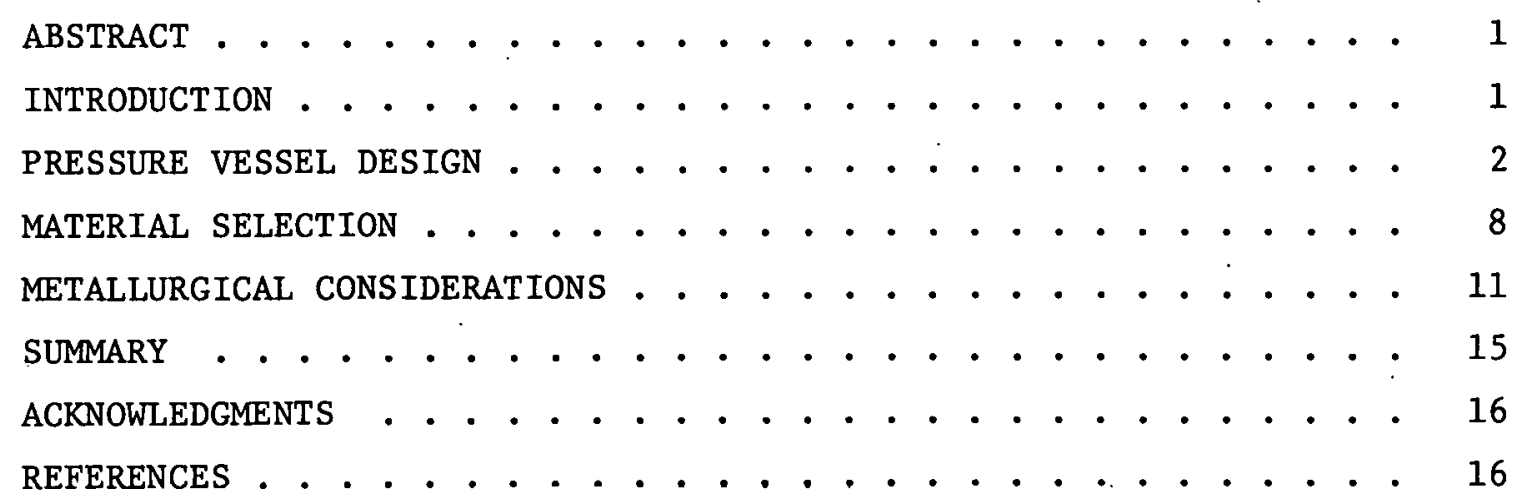




\title{
PRESSURE VESSELS FOR COAL CONVERSION SYSTEMS
}

D. A. Canonico, G. C. Robinson, * and W. R. Martin

\begin{abstract}
Pressure vessels for coal conversion systems, as suggested in some commercial conceptual designs, will be the largest units ever fabricated anywhere in the world. They will probably be designed to Section VIII. Further, because of their size and complexity they will probably be built to the rules of Division 2. Economics and operating conditions will dictate that these large vessels be fabricated from carbon and low-alloy steel plates and forgings that range from 0.2 to $0.3 \mathrm{~m}$ (8-12 in.) in thickness. Current ASME Code toughness requirements need to be reassessed for their adequacy to assure safe and reliable service over the 20 to 30 year design life of these vessels. An example is the minimum requirement of $20 \mathrm{~J}$ (15 $\mathrm{ft}-1 \mathrm{~b})$ for steels with ultimate tensile strength of $517 \mathrm{MPa}$ (75 ksi). Moreover, there are no rules in the Code that require that the owner consider the influence of process environment on the toughness of a pressure vessel during its operational lifetime.
\end{abstract}

\section{INTRODUCTION}

One of the most important factors that control the reliable and safe operation of a complex energy-related system is material rellability. ${ }^{1}$ This aspect of the commercialization of conversion processes is particularly evident in the experience ${ }^{2}$ to date with process development units and pilot plants that are currently operating under the sole sponsorship of ERDA or in cooperative ERDA/Industry programs. The ERDA survey ${ }^{2}$ reported in ERDA Newsletter No. 4 identified components that have failed; however, very few of these would have a major influence on the continued operation of a commercial coal conversion system. The unexpected failure of a major component will significantly affect plant availability. For

*Engineering Technology Division. 
example, replacement of a large pressure vessel could require from 2 to 4 years. ${ }^{3}$

The probability of the failure of one of these difficult-to-replace, long-lead-time components is affected by the operating conditions under which they must function. The potentially degrading effects of a harsh process stream environment combined with the temperature and pressure requirements of a number of the coal conversion processes will place unique operational demands upon these containment systems.

Our intent is to review areas that are considered to be of prime importance in assuring the reliable operation of large pressure vessels in commercial coal conversion systems. We have addressed, in particular, the role of design criteria, material selection, and metallurgical considerations.

\section{PRESSURE VESSEL DESIGN}

Vessel size is constrained by a number of factors that are not material dependent. These include fabrication procedure and component transportation. Fabrication procedure, shop vs field erection, is dictated by shop facilities. Currently, shop-fabricated vessels are limited to $1 \mathrm{Gg}$ (1000 tons) in mass and $11 \mathrm{~m}(35 \mathrm{ft}$ ) in diameter. Larger vessels must be field fabricated. The largest pressure vessel that can be transported any reasonable distance by railroad is $4.3 \mathrm{~m}$ $(14 \mathrm{ft}$ ) in diameter and about $0.8 \mathrm{Gg}$ (800 tons). Vessels up to $76 \mathrm{~m}$ long and $5.2 \mathrm{~m}$ in diameter ( 250 by $17 \mathrm{ft}$ ) have been shipped, ${ }^{4}$ but these are spectal situations involving short distances. The shipment of large pressure vessels by barge removes the size and weight constraints imposed by railroad transportation, but it does require that the coal conversion plants be sited on or near navigable waterways. The vessel size capable of being shipped by water is limited by shop capabilities. Navigable waterways are restricted ${ }^{5}$ to the eastern half of the United States. There are no navigable waterways much further west than eastern Oklahoma, and, therefore, the Northern Great Plains and the Rocky Mountains coal regions cannot be serviced by barge. 
The concept of employing prestressed concrete pressure vessels (PCRV) has been suggested. An Oak Ridge National Laboratory engineering team headed by Dr. W. L. Greenstreet is considering the merits of such containment. ${ }^{6}$ Figure 1 is a preliminary PCRV design conceived by that group for containing the gasification process in the Synthane coal conversion process. The PCRV concept lends itself to field erection.

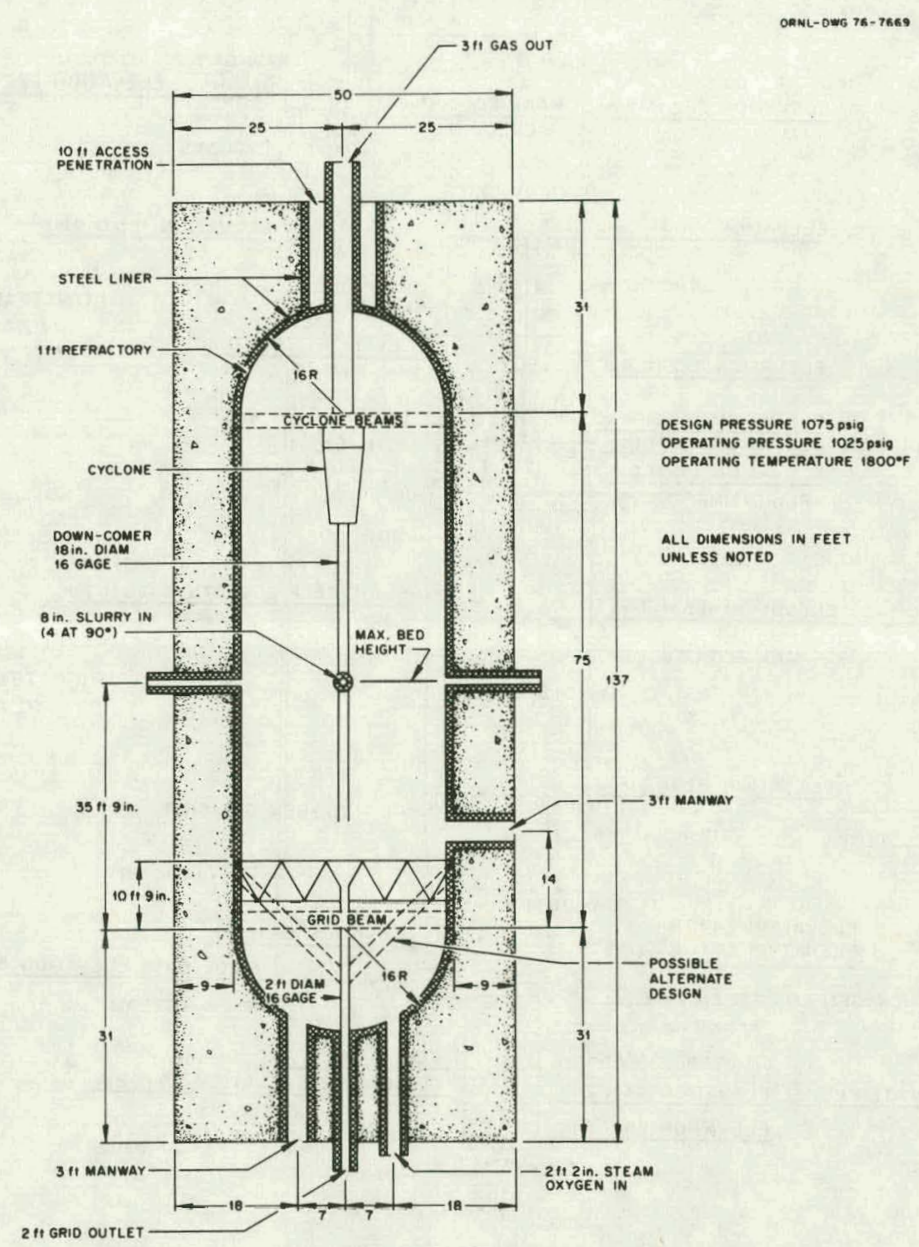

Fig. 1. Vertical Cross Section of Preliminary Conceptual Design of Synthane PCRV. To convert dimensions to meters, multiply feet by 0.3048 and inches by 0.0254 .

Currently, the industrial preference ${ }^{7}$ for commercial applications is toward large vessels, above $1 \mathrm{Gg}$ (1000 tons), and hence field fabrication procedures must be employed. Figure 2 is an example of a 
conceptual design for a gasifier for the HYGAS coal conversion system. ${ }^{6}$ These vessels will probably be built to Section VIII of the ASME Boiler and Pressure Vessel Code.

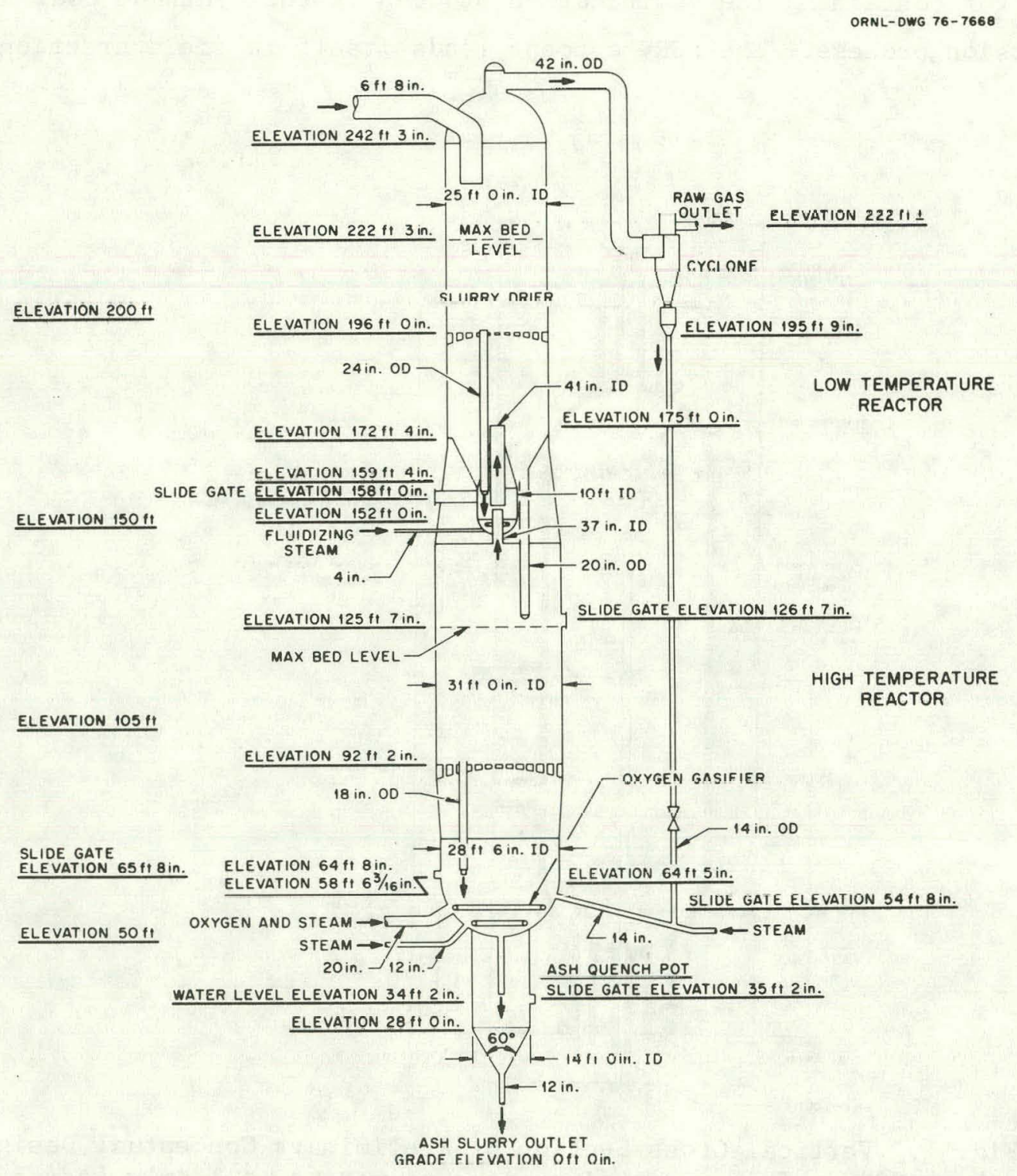

Fig. 2. HYGAS Gasifier Vessel. [Design pressure: $9.0 \mathrm{MPa}$ gage (1300 psig), design temperature: $\left.343^{\circ} \mathrm{C}\left(650^{\circ} \mathrm{F}\right)\right]$. To convert to meters, multiply feet by 0.3048 and inches by 0.0254 .

Section VIII has two Divisions, 1 and 2. The bases for establishing the stress values for each Division are provided in Table 1. The decision 
Table 1. Basis for Establishing Stress Values for Pressure Vessels Under ASME Section VIII

\begin{tabular}{|c|c|c|c|c|}
\hline \multirow{3}{*}{ Stress } & \multicolumn{4}{|c|}{ Fraction of Stress Used as Design Limit } \\
\hline & \multicolumn{2}{|c|}{ At Room Temperature } & \multicolumn{2}{|c|}{ Above Room Temperature } \\
\hline & Division 1 & Diviston 2 & Division 1 & Division 2 \\
\hline . & \multicolumn{4}{|c|}{ Ferrous Alloys } \\
\hline Ultimate tensile & $1 / 4$ of min & $1 / 3$ of $\mathrm{min}$ & $1 / 4$ & $1 / 3$ \\
\hline Yleld & $5 / 8$ of min & $2 / 3$ of $\mathrm{min}$ & $5 / 8^{a}$ & $2 / 3^{b}$ \\
\hline to Give $1 \times 10^{-5} / \mathrm{hr}$ creep rate & . & & $100 \%$ of av & c \\
\hline to Rupture in $100,000 \mathrm{hr}$ & & & $\begin{array}{l}67 \% \text { of av } \\
80 \% \text { of min }\end{array}$ & c \\
\hline Uniaxial strain-cycling fatigue & & $d$ & & d \\
\hline \multicolumn{5}{|c|}{ Nonferrous Alloys } \\
\hline Ultimate tensile & $1 / 4$ of $\mathrm{min}$ & $1 / 3$ of min & $1 / 4$ & $1 / 3$ \\
\hline Yield & $2 / 3$ of $\mathrm{min}$ & $2 / 3$ of min & $2 / 3^{a}$ & $2 / 3^{b}$ \\
\hline to Give $1 \times 10^{-5} / \mathrm{hr}$ creep rate & & & $100 \%$ of av & c \\
\hline to Rupture in $100,000 \mathrm{hr}$ & & & $\begin{array}{l}67 \% \text { of av } \\
80 \% \text { of min }\end{array}$ & c \\
\hline Uniaxial strain-cycling fatigue & & & & $\mathrm{d}$ \\
\hline
\end{tabular}

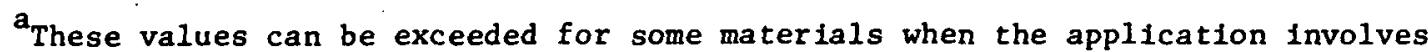
components where greater deformation is in itself not objectable, but cannot exceed $90 \%$ of minimum yield stress at temperature.

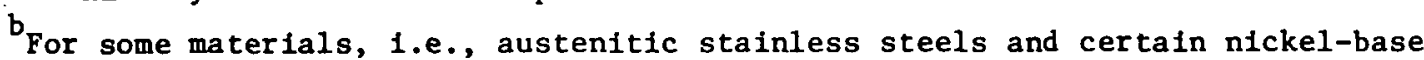
alloys, this value could be $90 \%$ of yield stress at temperature but cannot exceed $2 / 3$ of specified minimum yield stress at room temperature.

Criteria not established.

Fatigue properties are not always required; need for fatigue analysis is decermined by designer in accordance with paragraph AD-1602 of ASME Section VIII, Division 2 rules.

of which Code to apply rests with the Architect-Engineer (A-E) and his client. Some A-Es routinely perform a capital cost scoping study of vessels comparing Section VIII Division 1 against Division 2 at an early stage of conceptual evaluations. Small, light vessels of simple design are economically built to Division 1 rules, but a break-even point occurs such that relatively large, heavy complex vessels are more economically built to Division 2 rules. These vessels tend to be the gasifiers, hydro-gasifiers, $\mathrm{CO}-\mathrm{H}_{2}$ shift vessels, and methanators, and they undoubtedly 
will be designed in accordance with the rules of Division 2 of Section VIII. In addition, systems employing pressures greater than $21 \mathrm{MPa}$ (3000 psi) are not allowed under Section VIII Division 1 rules but are permitted under Section VIII Division 2.

To some degree the potential cost savings afforded by Division 2 through the use of thinner walled, lighter weight vessels is offset by the increased cost of using more rigorous rules of analysis and inspection.

Pressure vessels for coal conversion systems may lose their integrity and function by failures that are categorized as: (1) excessive elastir deformations resulting in unacceptable distortions of mating parts or in buckling; (2) flaw growth associated with initial fabrication flaws, stress concentrations, fatigue, environmental effects, etc., resulting in leakage or catastrophic brittle failure; (3) excessive plastic deformation resulting in plastic collapse or buckling; and (4) excessive creep deformation or creep rupture. Materials selection will be based upon economics and suitability for the intended service. Stresses and/or strains, including cyclic strains, may be calculated for an analytical model of the structure being assessed. These values of stress and strain may be compared with accepted values published in standards, such as Lhe ASME Pressure Vessel lodes. Such a procedure can properly be called "Design by Analysis." a procedure that is the basis of the ASME Code Section VIII, Division 2.

The analytical tools and degree of sophistication required to. satisfy a particular set of design rules vary radically with the design code selection. The ASME Code Section VIII Division 1 assumes that the Rankine theory of failure governs for material hehavior below creep limits; that is, the maximum principal stress calculated for a structure may be compared to the stress for a uniaxial test specimen at which yielding or failure has occurred. Rather than depend upon analysis as the primary basis for design, the philosophy ${ }^{9}$ of Section VIII Division 1 (as well as Section I) has been to determine wall thickness from a simple calculation of hoop stress that cannot exceed a very conservative allowable stress level. This conservative thickness determination 
coupled with required fabrication details results in a design that generally accommodates high local and secondary stresses that exist for structures built according to Division 1 rules. These design procedures thereby avoid extensive and complex stress analysis of the structure.

The procedures of Division 1 of Section VIII have generally been satisfactory for vessels employed in conventional service; however, for vessels to be used in these new conversion concepts and to ensure a high degree of reliability, it would be advantageous to design according to Division 2 of Section VIII (i.e., "Design by Analysis"). Division 2 uses the Tresca criterion (maximum shear stress theory), which states that yielding takes place when the maximum shear stress is equal to one-half the yield strength of the material. Limit theory is used by Division 2 to categorize stresses as "primary," "secondary," and "peak" such that (1) the primary stress limits prevent plastic deformation and provide a safe design margin against ductile failure, (2) the primary plus secondary stress limits prevent plastic deformation leading to incremental collapse and validate the application of elastic analyses to fatigue evaluation, and (3) the peak stress limit prevents fatigue failure as a result of cyclic loading. Stress limits are also provided by Division 2 to prevent elastic and inelastic instability.

Elevated-temperature design is handled under Division 1 by basing the allowable stresses on creep rate and rupture data ${ }^{10}$ extrapolated to $100,000 \mathrm{hr}$. Current Division 2 rules do not provide for elevatedtemperature design.

Neither Division 1 nor Division 2 analyzes the potential of lowtemperature brittle fracture or analyzes the load carrying capability of flawed vessels for any range of service temperatures. Material selection and material toughness specifications, determined by the Charpy $-\mathrm{V}\left(\mathrm{C}_{\mathrm{V}}\right)$ test, provide the primary protection against brittle fracture. Fracture mechanics has experienced a tremendous growth in understanding and application in the last 20 years. Although initially limited to assessments of flawed vessels loaded under frangible conditions, its applicability into the elastic-plastic regime now has been demonstrated. 
Section XI of the ASME Code now uses the discipline for in-service assessment of flawed nuclear components. Concise descriptions of analytical fracture mechanics techniques that have demonstrated utility for analyzing flawed structures for both the elastic and elastic-plastic regimes are available from a number of sources.11,12

\section{MATERIAL SELECTION}

The ASME Code Section II Part A provides specifications for plate and forging steels that can be considered for thick-walled cnal rnnversion system pressure vessels. Consideration of all. possihle materials would be prohibitive; however, the conceptual designs that have been completed by some engineering firms do suggest a number of 1ikely materials. The fabrication of the large pressure vessels will probably be limited to plain carbon and low-alloy high-strength steels. Three examples of candidate steel specifications are provided in Table 2. Similar steels are available as forgings. Probably the forging grades will be favored for extremely large thick-walled pressure vessels. The wall thicknesses of the pressure vessels will be limited to a maximum of about $0.33 \mathrm{~m}$ (13 in.). Two factors dictate this upper limit on thickness, (1) the steel's ability to achieve minimum tensile requirements and (2) the facricators' ability to form thick sections. The plain carbon steels represented by SA-516 Grade 70 are limited to a maximum thickness of $0.2 \mathrm{~m}$ (8 in.). The alloy steels' maximum thickness is either ( 1 ) specifled $i n$ the SA specification (see $\overline{S A}-533$ Grade B Class 1) or (2) controlled by the steel's hardenability (see SA-387 Grade 22 Class 2). Frequently, interest is shown in higher strength steels, but usually these are not ASME Code approved. Table 2 contains A 543, an example of a plate specification for steels that have ultimate teneile otrangths in excess of $689 \mathrm{MPa}(100,000 \mathrm{psi})$. This specification is a commercial adaptation of the submarine hull steels commonly referred to as HY 80 . Similar forging grades, A 508 Classes 4 and 5, also exist. A coile case has been proposed that would permit the use of A $543 \mathrm{Class} 1$ for welded construction under the rules of Section VIII. 
Table 2. Candidate Plate Steels for Pressure Vessels with Required Wall Thicknesses Greater than $0.1 \mathrm{~m}$ (4 in.)

\begin{tabular}{|c|c|c|c|}
\hline Steel Identification ${ }^{a}$ & $\mathrm{SA}-387$ & $\mathrm{SA}-516$ & A 543 \\
\hline Grade and Class & 22,2 & 55 & $B, 1$ \\
\hline \multicolumn{3}{|l|}{ Max Content and Range, wt \% } & 0.23 \\
\hline Manganese & $0.27-0.63$ & $0.56-1.25$ & 0.40 \\
\hline Phosphorus & 0.035 & 0.035 & 0.020 \\
\hline Sulfur & 0.035 & 0.04 & 0.020 \\
\hline Silicon & 0.50 & $0.13-0.33$ & $0.20-0.35$ \\
\hline Molybdenum & $0.85-1.15$ & & $0.45-0.60$ \\
\hline Nickel & & & $3.00-4.00$ \\
\hline Chromium & $1.88-2.62$ & & $1.50-2.00$ \\
\hline $\begin{array}{l}\text { Max Available Plate Thickness, } \\
\text { m (in.) }\end{array}$ & c & $0.3(12)$ & c \\
\hline \multicolumn{4}{|l|}{ Strength, MPa (ksi) } \\
\hline U1timate tensile & $\begin{array}{l}517-689 \\
(75-100)\end{array}$ & $\begin{array}{l}379-448 \\
(55-65)\end{array}$ & $\begin{array}{l}724-862 \\
(105-125)\end{array}$ \\
\hline Max Yield Point & $310(45)$ & $207(30)$ & $586(85)$ \\
\hline Max Elongation (in 2 in.), $\%$ & 22 & 27 & 14 \\
\hline Max Reduction of Area, \% & 40 & & \\
\hline
\end{tabular}

${ }^{a}$ SA denotes ASME Section II Part A. A denotes ASTM specification.

$\mathrm{b}_{\text {Maximum carbon content based on requirements for thickest }}$ plates.

Maximum thickness is 1 imited only by the capacity of the chemical composition to meet specified minimum mechanical properties. 
The advantages of employing high-strength steels are evident when the allowable stress values are compared. Table 3 contains the allowable s.tress values for SA-516 Grade 55 [available as 0.3 m-thick (12-in.) plate], SA-387 Grade 22 Class 2, and A 543 Class 1 . This table also compares the Division 1 and Division 2 allowable stresses in Section VIII.

Table 3. Comparison of the Section VIII Maximum Allowable Stress Values in Division 1 and the Design Stress Intensity Values in Division 2

\begin{tabular}{|c|c|c|c|c|c|c|c|}
\hline \multirow{2}{*}{\multicolumn{2}{|c|}{ Temperațure }} & \multicolumn{6}{|c|}{ Dco1gn Limit, MPa $(k v i)^{a}$} \\
\hline & & \multicolumn{2}{|c|}{ SA-5i6 Grade 55} & \multicolumn{2}{|c|}{ SA-387 Ǵade 22 تlass 2} & \multicolumn{2}{|c|}{ A. 343 Elass $1^{b}$} \\
\hline & & Division 1 & Division 2 & Division 1 & Division 2 & Division 1 & Division 2 \\
\hline 38 & 100 & $94(13.7)$ & $126(18.3)$ & $129(18.7)$ & $172(25.0)$ & $181(26.3)$ & $241(35.0)$ \\
\hline 204 & 400 & $94(13.7)$ & $119(17.2)$ & $120(17.4)$ & $160(23.2)$ & $1.79(26.0)$ & $.239(34.6)$ \\
\hline 343 & 650 & $94(13.7)$ & $100(14.5)$ & $119(17.2)$ & $158(22.9)$ & $173(25.1)$ & $231(33.5)$ \\
\hline
\end{tabular}

${ }^{a}$ SA indicates an ASME Code Section II Part A specification. A indicates an ASTM standard.

${ }^{b}$ A code case has been proposed to permit the use of A 543 under the rules of Section VIII for welded construction.

The ASME and ASTM specifications do not have specific requirements for qualifying materials for elevated-temperature and assoclated process environmental conditions. All that is required is that the material satisfy the minimum mechanical property requirements at room temperature and the other requirements of the specification. Allowable stresses are provided for each Code-approved material; howevèr, these values are based on tests performed on test heats of that grade and experience with that alloy grade, and no elevated-temperature tests are required to assure that a given heat of steel satisfies the minimum values upon which the allowable stresses are based. The ASME Code requires that the designer consider environmental effects, but provides no specific guidance or rules. Hence, the integrity of a system depends on the experience and expertise available to the designer. In the case of most coal conversion systems the information regarding specific process conditions is limited. Most of the experience upon which a judgment of 
environmental effects is based is being obtained in Process Development Unit (PDU) and Pilot Plant (PP) operations. The much greater size of commercial plants may introduce effects that cannot be measured in or extrapolated from the experience with a small experimental setup.

\section{METALLURGICAL CONSIDERATIONS}

The choice of material for fabrication of a component depends on the volume of the process stream (this will determine the vessel's diameter and height), its chemical characteristics (corrosivity of the process stream), the required temperature and pressure, and the acceptability of the material under the Code. These criteria will dictate whether the component will operate in the cold mode $\left[\leqslant 340^{\circ} \mathrm{C}\left(650^{\circ} \mathrm{F}\right)\right]$ or hot mode (above the temperature for which creep must be considered). The pressure vessels used in coal conversion systems will likely operate below the creep range and above the dew point of the process stream. The limitations are selected because at the temperatures for which time-dependent properties must be considered, the Code allowable stresses decrease rapidly for small increases in design temperature. This is particularly true for the ferrous materials. The high-alloy materials (austenitic stainless steels and high-nickel alloys) maintain their strength to higher temperatures, but generally their allowable stress levels are low and their cost per fabricated pound is comparatively high. Hence, the large pressure vessels will be fabricated from carbon or low-alloy steels and they will be protected from the high process temperatures by refractory insulation and perhaps overlaid (or clad) to protect them from the process stream. Further, the desirability of minimizing the number of trains will require that the pressure vessel be large in diameter, thereby necessitating thick walls.

Section sizes such as these demand that the plates (and forging courses) be processed from ingots that will only permit minimal working ${ }^{13}$ during slabbing and rolling. For thick sections $[\approx 0.3 \mathrm{~m}$ (12 in.)] the amount of reduction is near 3.3 to 1 and the cross rolling ratio is about 1.7. After processing it is necessary to quench and temper these massive sections to achieve the required tensile properties at the 
1/4-thickness location. This test location is specified for materials. that are cooled in a medium that provides a cooling rate faster than that of still air. For example, SA-336 Class.F22 steel (referred to as normalized and tempered), a forging grade of $21 / 4 \mathrm{Cr}-1$ Mo steel, is usually quenched and tempered in thick sections. By quenching and tempering the minimum tensile requirements of the specification can easily be achieved even in the maximum sizes available today, about $0.36 \mathrm{~m}$ (14 in.). The low cross rolling ratio cited above will result in some anisotropy, ${ }^{14}$ which is most apparent when toughness properties are compared. Figure 3 contains $C_{V}$ data for SA-533 Grade B Class 1 steel as a function of temperature for different specimen orientations. Specimen orientation has 1ittle effect on the toughness in the transition temperature region; however, the effect of the cross rolling is reflected in a difference in the upper-shelf energy values.

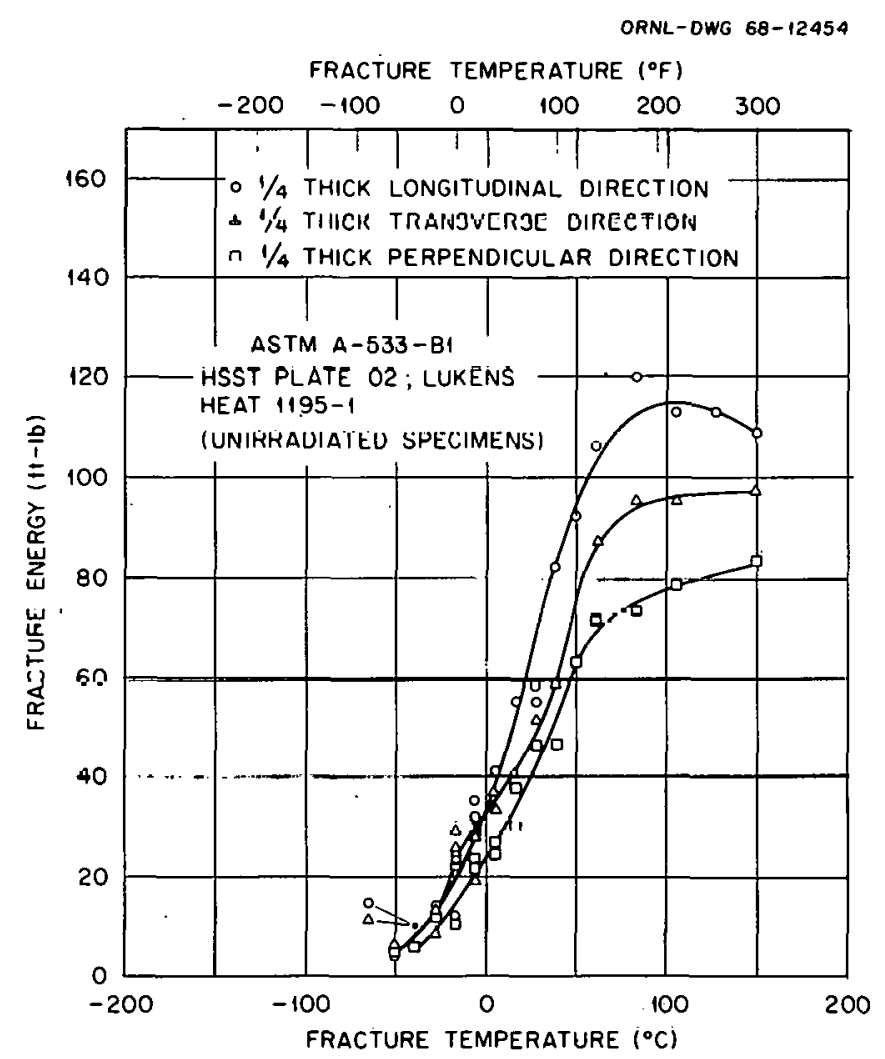

Fig. 3. Effect of Specimen Orientation on the Charpy V Notch Impact Toughness of 305-mm-Thick (12-in.) A 533 Grade B Class 1 Steel Plate. To convert energy to Joules, multiply by 1.356 . 
Quenching and tempering of carbon and low-alloy steels results in a variation in properties through the plate thickness. ${ }^{14}$ Such a variation caused by quenching is illustrated in Fig. 4. As mentioned above, the codes require that the minimum requirements of the specification be satisfied at the 1/4-thickness location, and, consequently, quite of ten the properties are not determined at the other depths. The surface properties are superior to those at the 1/4-thickness location because of the faster cooling rate there. The ultimate tensile strength is much higher than what would be nominally reported for this heat of steel. For

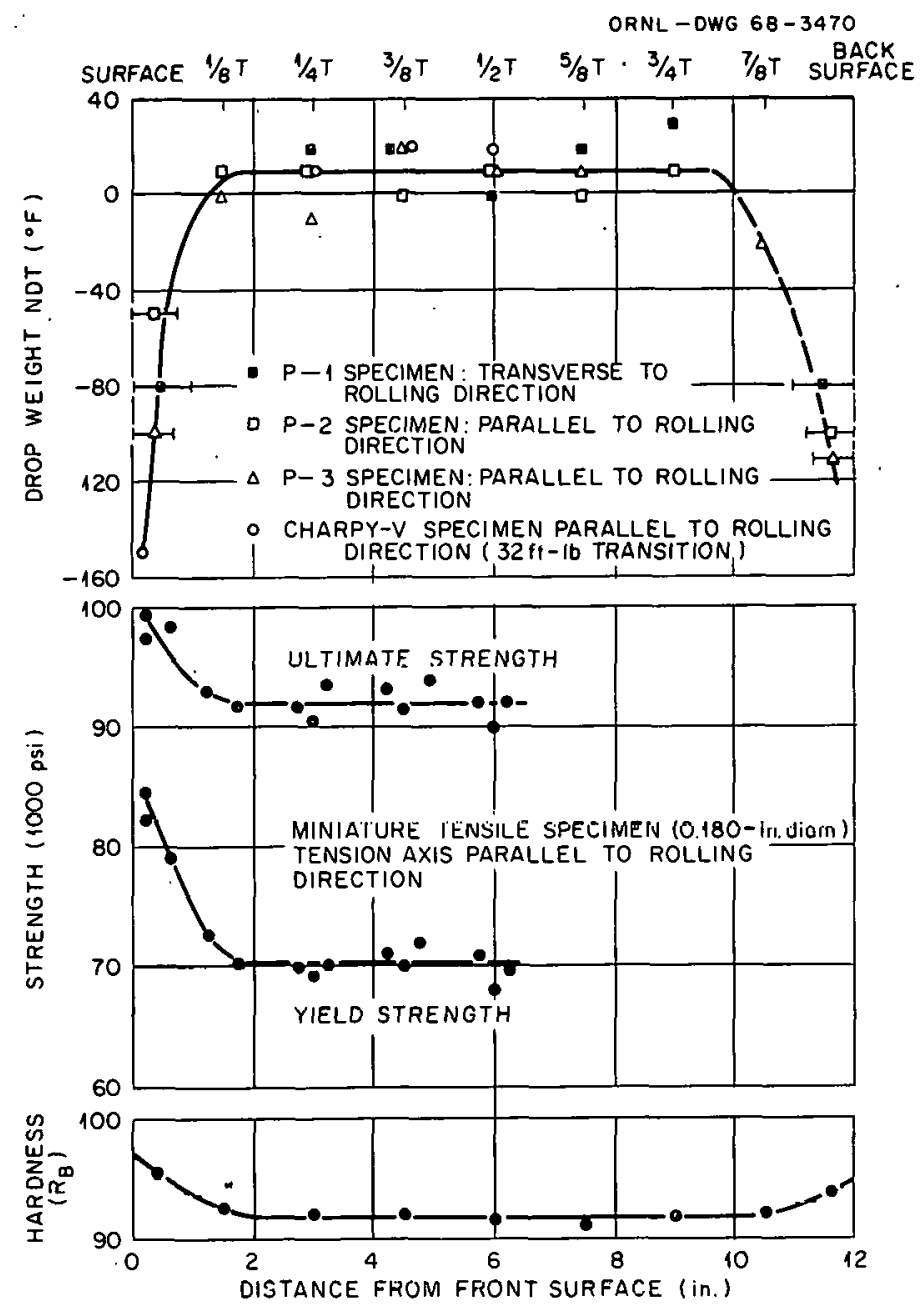

Fig. 4. Effect of Quenching (and Tempering) on the Through-theThickness Variation in Properties of 305-mm-Thick (12-in.) Plate of A 533 Grade B Class 1 Steel. 
certain applications, this increase in strength is beneficial. In the case of a coal conversion system, the increased strength in the surface could be detrimental. A National Ássociation of Corrosion Engineers (NACE) Committee reported ${ }^{15}$ that carbon and low-alloy steel candidates for the fabrication of vessels for coal conversion systems are susceptible to sulfidization attack when their hardness is about $\mathrm{R}_{C} 22$ or greater.

It is evident from the above discussions that the required tensile properties can be achieved even in the extremely thick section sizes by quenching and tempering. Notch toughness per se, particularly the requirements of Section VIII Divisions 1 and 2 of the ASME Code, can be met by the candidate alloys being proposed for coal conversion pressure vessels; however, the adequacy of these requirements must be questioned.

Most disruptive pressure vessel failures reported in the open 11terature have occurred as a consequence of poor initial toughness or because of a loss of toughness as a result of service. The Thompson vessel, ${ }^{16}$ which failed in England during hydrostatic testing in 1966, is a classical example of the effect of poor initial toughness. The failure of a Japanese desulfurization reactor ${ }^{17}$ during field repair work demonstrates the combined effects of service-related crack initiation, crack growth rate, and an environment that embrittled the base metal.

The Thompson vessel represents the catastrophic end point of an incorrect postweld heat treatment (PWHT). Available ${ }^{18}$ data show that extended time or higher temperatures during PWHT can embrittle low-alloy high-strength steel and welds. This embrittlement manifests itself as an increase in the transition temperature and a lowering of $\mathrm{C}_{V}$ upper-shelf energy. 'lhe l'hompson vessel fortunately failed during a (British) Coderequired hydrostatic test, although at a high cost in both time and money.

The process environment that is inherent in these conal. conversion pressure vessels will require that the vessels be clad. The procedure for cladding often results in the presence of microfissures or cracks in or under the cladding. Both phenomena have duplex structures with ready-made initiation sites, which increase the potential for crack growth during service. It has been established that environment will usually affect crack growth rates. 
The current toughness criteria of Section VIII of the ASME Code are minimal. They are based on a $C_{V}$ notch criterion that is appropriate for thin sections of plain carbon steels: The requirements are 14 to $27 \mathrm{~J}$ $(10-20 \mathrm{ft}-1 \mathrm{~b})$ [or $0.38 \mathrm{~mm}$ (15 mil) lateral expansion], depending on the strength of the steel in both Divisions 1 and 2 of Section VIII. The Code does not have an upper-shelf toughness requirement. Further, the Code contains no rules that are related to the influence of environment on toughness. The Section VIII Code criteria are based on crack initiation criteria that evolved from post-World-War-II ship failure investigations. Those fallures initiated and propagated from extremely small flaws in base materials that were $38 \mathrm{~mm}$ ( $1.5 \mathrm{fn}$.) and less in thickness. The pressure vessels proposed for coal conversion systems will be fabricated from thick plates and forgings, and cracks can grow to sizes that can be critical even for materials that meet a $20-\mathrm{J}$ (15 $\mathrm{ft}-1 \mathrm{~b}$ ) or $0.38 \mathrm{~mm}$ (15 mil) lateral expansion criterion. For example, the A 533 Grade B Class 1 steel used to develop the $K_{I R}$ curve in Appendix $G$ of Section III of the ASME Code exhibited fractures that satisfied the criteria for a valid linear elastic failure ${ }^{19}$ mode in $0.1-\mathrm{m}$-thick (4 in.) steel at $-18^{\circ} \mathrm{C}\left(0^{\circ} \mathrm{F}\right)$. This material meets the $20 \mathrm{~J}(15 \mathrm{ft}-1 \mathrm{~b}) \mathrm{C}_{\mathrm{V}}$ criterion $^{14}$ at about $-23^{\circ} \mathrm{C}\left(-10^{\circ} \mathrm{F}\right)$. A $20 \mathrm{~J}(15 \mathrm{ft}-1 \mathrm{~b})$ criterion at $-23^{\circ} \mathrm{C}\left(-10^{\circ} \mathrm{F}\right)$ would not assure safe and reliable behavior for 0.2 to $0.3-\mathrm{m}$-thick (8-12 in.) pressure vessels. In reality, a $0.3-\mathrm{m}-\mathrm{thick}$ (12 in.) steel section failed in a frangible mode at more than $39^{\circ} \mathrm{C}\left(70^{\circ} \mathrm{F}\right)$ above the temperature at which the steel absorbed $20 \mathrm{~J}$ (15 ft-1b) in a $C_{V}$ test. The use of a 20 or $27 \mathrm{~J}$ (15 or $20 \mathrm{ft}-1 \mathrm{~b}) \mathrm{C}_{\mathrm{V}}$ value to determine the adequacy of the toughness of $a .2$ to $0.3-\mathrm{m}$-thick (18-12-in.) pressure vessel steel to avoid the initiation of a fracture needs to fully assessed. Reliability of new synthetic fuel plants is a must if they are to satisfy the future energy needs of the I. . S.

\section{SUMMARY}

The pressure vessels required for commercial coal conversion systems are long-lead-time, difficult-to-replace items. It is granted that current technology can provide materials that satisfy the minimum property 
requirements of today's codes. However, these codes were developed for units that do not operate under combinations of variable process stream conditions that are as harsh as those that will be encountered in commercial coal conversion systems. Further, the extremely thick-walled vessels that are proposed in a number of conceptual designs may not provide the margins of safety. and reliability that thinner walled materials can assure; in particular, the conservativeness of a leak before fracture criterion.

\section{ACBNOWLEDGMINTS}

The authors are indebted to Wanda Butcher for typing the original manuscript and the ORNL Metals and Ceramics Division Reports Office personnel, particularly S. Peterson and Stephanie Davison respectively, for editing and preparing the final draft for publication.

\section{REFERENCES}

1. Interagency Task Group on Power Plant Rellability, A Report on Improving the Productivity of Electric Power Plants, Office of Energy Conversion, Energy Resource Development, Federal Energy Administration, March 1975.

2. Materials and Components in Fossil Energy Applications, ERDA Newsletter No. 4, April 1, 1976.

3. W. L. Hicklin, "The Construction of Coal Conversion Vessels," presented at Clean Fuels from Coal Conference, Institute of Gas Technology, June 23-27, 1975.

4. Chem. Eng. 83(71): 38 (Aug. 16, 1976).

5. Superintendent of Documents Stock No. 4118-00029, Project Independence Report, Federal Energy Administration, Washington, November 1974.

6. W. L. Greenstreet, "Prestressed Concrete Pressure Vessel Studies," Coal Technology Program Annual Interim Report for Fiscal Year Ending June 30, 7976, ORNL-5208 (to be published). 
7. R. D. Howell, "Mechanical Design Considerations in Commercial Scale Coal Gasification Plants," pp. 317-38 in Proc. 6th Synthetic Pipeline Gas Symposium (held in Arlington, Va., Oct. 28, 1974), American Gas Association, 1974.

8. Criteria of the ASME Boiler and Pressure Vessel Code for Design by Analysis in Sections III and VIII, American Society of Mechanical Engineers, New York, 1969.

9. B. F. Langer, "Design-Stress Basis for Pressure Vessels," Exp. Mech. 11: 1 (January 1971).

10. R. E. Peterson, Stress Concentration Design Factors, John Wiley and Sons, Inc., New York, 1953.

11. "Pressure Vessel Research Committee Task Croup on Toughness Requirements, Discussion of Fracture Analysis Methods for Structural Components," draft copy dated May 14, 1975 (to be published as a Welding Research Council Bulletin).

12. P. C. Paris, "Fracture Mechanics in the Elastic-Plastic Regime," Paper III-1 in Proceedings of the Technology Information Meeting on Methods for Analyzing Piping Integrity (ERDA-sponsored meeting held November 11-12, 1975 at ERDA, Germantown Facility), ERDA 76-50.

13. C. E. Childress, Fabrication History of the Third and Fourth ASTM A 533 Steel Plates of the Heavy Section Steel Technology Program, ORNL-TM-4313-2 (February 1970).

14. D. A. Canonico and R. G. Berggren, "Tensile and Impact Properties of Thick-Section Plate and Weldments," Nucl. Eng. Des. 17(1): 4-15 (Auguet 1971).

15. "NACE Unit Committee T-1F Report," Mater. Prot. 5(a): 81-82 (September 1966).

16. R. Weck, "Brittle Fracture of a Thick Walled Pressure Vessel," $B r$. Weld. Res. Assoc. BuZZ. 7(6) (June 1966).

17. J. Watanabe et al., "A Fracture Safe Analysis of Pressure Vessels Made of $21 / 4 \mathrm{Cr}-1$ Mo Stee1," Paper 126 presented at Corrosion/76, The International Corrosion Forum Devoted Exclusively to the Protection and Performance of Materials, March 22-26, 1976, Houston, Texas. 
18. W. J. Stelzman and D. A. Canonico, "Characterization of Pressure Vessel Steels," Quart. Prog. Rep. on the Heavy Section Steel Technology Program July-September 1975, ORNL-IM-5170, pp . 22-24.

19. T. R. Mager, "Fracture Toughness Properties of Heavy Section A 533, Grade B Class 1 Steel Plate and Submerged Arc Weldment," Nucl. Eng. Des. 17(1): 76-90 (1971). 
ORNL/TM-5685

Distribution

Category UC-90d

INTERNAL DISTRIBUTION

1-2. Central Research Library

3. Document Reference Section

4-8. Lahoratory Records Department

9. Laboratory Records, ORNL RC

10. ORNL Patent Office

11. G. M. Adamson

12. R. J. Beaver

13. R. G. Berggren

14. C. R. Brinkman

15-22. D. A. Canonico

23. H. D. Cochran, Jr.

24. R. A. Cooper

25. R. H. Cooper, Jr.

26. F. L. Culler

27. J. E. Cunningham

28. J. H. DeVan

29. J. R. DiStefano

30. R. G. Donnelly

31. M. S. Edwards

32. C. G. Fee

33. D. E. Ferguson

34. L. M. Ferris

35. Jurgen Föh1

36. R. C. Forrester III

37. A. P. Fraas

38. W. Fulkerson

39-41. M. R. Hill
42. J. M. Holmes

43. R. T. King

44. C. T. Liu

45. C. J. Long

46-52. W. R. Martin

53. H. E. McCoy

54. R. W. McClung

55. C. J. McHargue

56. J. R. McWherter

57. R. K. Nanstad

58. J. P. Nichols

59. R. E. Pawe1

60. T. W. Pickel

61. W. W. Pitt

62. H. Postma

63-68. G. C. Robinson

69. T. K. Roche

70. M. W. Rosentha1

71. Royes Salmon

72. A. C. Schaffhauser

73. C. D. Scott

74. W. D. Shults

75. G. M. Slaughter

76. W. J. Stelzman

77. D. B. Trauger

78. J. R. Weir, Jr.

79. G: D. Whitman

EXTERNAL DISTRIBUTION

80. BABCOCK \& WILCOX COMPANY, Power Generation Group, 20 South Van Buren Avenue, Barberton, Ohio 44203

P. M. Brister, Manager

8.1-84. MORGANTOWN ENERGY RESEARCH CENTER, P.0. Box 800, Morgantown, WV 26506

Director 
85-100. ERDA, Washington, DC 20545
W. Baker, FER
D. Garret, FDP
J. D. Batchelor, CCU
S. W. Couse, FE
E. L. Clark, CCU
W. S. Harmon, FDP
N. P. Cochran, FDP
L. Kindley, FER
T. Cox, FER
C. Knudsen, FER
S. J. Dapkunas, FER
T. K. Lau, FDP
J. Forst, FE
J. Smith, FE
H. Frankel, FE
D. K. Stevens, DPR

101-103. ERDA PITTSBURGH ENERGY RESEARCH CENTER, 4800 Forbes Avenue, Pittsburgh, PA 15213
W. J. McMichaels
W. P. Hnynco
J. P. Etrakey

104. ERDA FOSSIL ENERGY ANALYST, Office of Congressional Relations, Washington, DC 20545

David 0. Webb

105-106. ERDA OAK RIDGE OPERATIONS OFFICE, P.O. Box E; Oak Ridge, TN 37830

Director, Reactor Division

Director, Research and Technical Support Division

107-324. ERDA TECHNICAL INFORMATION CENTER, Office of Information Services, P.0. Box 62, Oak Ri.dge, TN 37830

For distribution as shown in TID-4500 Distribution Category, UC-90d (Coal Conversinn and Utilization - Liquefactioi) 